\title{
INFLUENCE OF INFORMATION ABOUT THE BENEFITS OF CONSUMING FRUIT ON CONSUMER PREFERENCES IN TEMUCO, REGION OF THE ARAUCANÍA ${ }^{1}$
}

\author{
BERTA SCHNETTLER ${ }^{2}$, GERMÁN LOBOS ${ }^{3}$, HORACIO MIRANDA ${ }^{4}$, \\ LIGIA ORELLANA $^{5}$, KLAUS G. GRUNERT ${ }^{6}$
}

\begin{abstract}
With the aim of identifying strategies to increase fruit consumption in Temuco, consumer segments were classified according to the importance and preference of the attributes type of fruit, package/ brand, benefit associated with fruit consumption and price. A survey was applied to 400 people in Temuco, Chile, distributed using a simple allocation: 200 working adults and 200 university students. The questionnaire included the SWFL (Satisfaction with Food-related Life) scale, respondents' fruit consumption habits and their characteristics. Using conjoint and cluster analyses, three segments were distinguished: Group 1 $(22.0 \%)$ gave greatest importance to the package/brand and preferred the message "prevents diseases" and "without information"; Group 2 (47.5\%) gave greatest importance to the package/brand and preferred the message "prevents diseases"; Group 3 (30.5\%) assigned greatest importance to the price and preferred the message "contains antioxidants". The segments differed in their level of satisfaction with food-related life, self-declared lifestyle, age and presence of university students. The results provide input to promote fruit consumption in working adults and university students.
\end{abstract}

Index terms: Fruits, health benefits, Chile.

\section{INFLUENCIA DE LA INFORMACIÓN DE LOS BENEFICIOS DEL CONSUMO DE FRUTAS EN LAS PREFERENCIAS DEL CONSUMIDOR EN TEMUCO, REGION DE LA ARAUCANÍA}

RESUMEN - Con el objetivo de identificar estrategias para incrementar el consumo de frutas en Temuco, se identificaron segmentos de consumidores según la importancia y preferencia hacia los atributos: especie de fruta, envase/marca, beneficio asociado al consumo de la fruta y precio. Se aplicó una encuesta a 400 personas de la ciudad de Temuco, sur de Chile, distribuidas mediante afijación simple: 200 adultos laboralmente activos y 200 estudiantes universitarios. El cuestionario incluyó la escala SWFL (Satisfaction with Food-related Life), hábitos de consumo de frutas y características de los encuestados. Mediante análisis conjunto y clúster se distinguieron tres segmentos: Grupo 1 (22.0\%) dio mayor importancia al envase/marca, prefirió el mensaje "previene enfermedades" y "sin información"; Grupo 2 (47,5\%) dio mayor importancia al envase/marca, prefirió el mensaje "previene enfermedades"; Grupo 3 (30.5\%) asignó mayor importancia al precio, prefirió la mensaje "contiene antioxidantes". Los segmentos difirieron en su nivel de satisfacción con la alimentación, estilo de vida auto declarado, edad y presencia de estudiantes universitarios. Los resultados entregan insumos para promover el consumo de fruta tanto en adultos laboralmente activos como en estudiantes universitarios. Términos de indexación: Frutas, beneficios para la salud, Chile.

\footnotetext{
${ }^{1}$ (Trabalho 201-14). Recebido em: 18-07-2014. Aceito para publicação em: 20-05-2015.

${ }^{2}$ Dra., Facultad de Ciencias Agropecuarias y Forestales, Universidad de La Frontera. Avenida Francisco Salazar 01145, Temuco, Chile. E-mail: berta.schnettler@ufrontera.cl

${ }^{3}$ Dr., Interdisciplinary Excellence Research Program on Healthy Ageing (PIEI-ES), Facultad de Economía y Negocios, Universidad de Talca. Chile. E-mail: globos@utalca.cl

${ }^{4}$ MSc., Facultad de Ciencias Agropecuarias y Forestales, Universidad de La Frontera. Chile. E-mail: horacio.miranda@ufrontera.cl ${ }^{5} \mathrm{MSc}$, Centro de Psicología Económica y del Consumo. E-mail: ligia.orellana@ufrontera.cl

${ }^{6}$ Dr., MAPP Centre for Research on Customer Relations in the Food Sector, Aarhus University, Denmark. E-mail: klg@badm.au.dk
} 


\section{INTRODUCTION}

According to estimates by the Information Centre of Natural Resources (CIREN) for different regions of Chile, the surface for fruit plantations in the country has increased steadily in recent years. The total planted area increased from 215,443 to 293,741 hectares between 2002 and 2012, an increase of $36.3 \%$ over that period (ODEPA, 2013). Based on information by ODEPA (2013), species occupying the largest proportion of plantings correspond to grapevine (18.2\%), apples (12.6\%) and avocado $(12.1 \%)$, but the fruits with a higher growth in the period are blueberries (976.8\%), olives (195.7\%) and cherries (127.1\%). Exports continue capturing about $60 \%$ of the national fruit production in most species. The Chilean fruit industry has become leader and has maintained this leadership as the largest exporter of fresh fruits in the southern hemisphere, as well as a leading world exporter of grapevines and blueberries, the second largest exporter of avocados, and the third largest exporter of cherries, plums and kiwis (ODEPA, 2013).

The surface for fruit plantations in Chile is mainly concentrated in the central area of the country. $78.4 \%$ of this surface corresponds to the regions of Valparaíso, the Metropolitan area, Libertador General Bernardo O'Higgins and Maule (ODEPA, 2015). The Region of the Araucanía concentrates only $2.5 \%$ of the surface for fruit plantations in 2012, corresponding to 7.303 hectares, out of which apples (33.9\%), European hazelnuts (30.8\%), blueberries (21.4\%) and cherries (5.2\%) stand out as the species with the most land in the region (ODEPA, 2015). However, despite the low concentration of land for fruit plantation in La Araucanía, there is a notable increase of $95.3 \%$ registered between 2006 and 2012 (CIREN, 2012).

Consumption of diets rich in fruits and vegetables $(\mathrm{F} \& \mathrm{~V})$ has been extensively demonstrated to be important for attaining and maintaining a good health (VAN DUYN \& PIVONKA, 2000). Eating fresh $F \& V$ prevent weight gain and can reduce the risk of chronic diseases, including heart disease, diabetes, and cancer (HAYNES-MASLOW et al., 2013), which means $\mathrm{F} \& \mathrm{~V}$ can be counted as functional foods (PELAYO, 2003). In addition, F\&V consumption has a positive effect on mental health, contributing to subjective well-being (BLANCHFLOWER et al., 2013). The World Health Organization recommends a daily intake of at least $400 \mathrm{~g}$ of $\mathrm{F} \& \mathrm{~V}$ (WHO, 2003). Nevertheless, F\&V consumption is below recommended levels (VERBEKE \& PIENIACK, 2006), mainly in developing countries
(OLAVARRIA; ZACARIAS, 2011). The obstacles to greater $\mathrm{F} \& \mathrm{~V}$ consumption are: high cost (BEHE, 2006; PEROSA et al., 2012; HAYNES-MASLOW et al., 2013), lack of quality and variety (PEROSA et al., 2012; HAYNES-MASLOW et al., 2013), poor knowledge of nutrition (SCHNETTLER et al., 2011), and lack of effective promotional campaigns (OLAVARRIA; ZACARIAS, 2011), among others.

A person's likelihood of purchasing a functional food depends on the consumer's ability to link the functional characteristics of the product to the consequences of consuming it. Thus, consequencerelated knowledge about the functional food (e.g., the product contributes to the preservation of bone health) increases the likelihood of consumption to a larger extent than knowledge only related to the functional ingredient (e.g. contains extra calcium) (WASKING el al., 2005). In Belgium, Geeroms et al. (2008) detected three consumer segments $(50 \%$ in total) that responded positively to verbal arguments, paying attention to the functional benefits of $\mathrm{F} \& \mathrm{~V}$ (e.g. avoiding illness or avoiding getting obese). However, to our knowledge, studies of this type specifically in fruits have not been conducted in South American countries.

This is particularly relevant in South American countries, where the food situation is related to socio-demographic, economic, dietary and lifestyle changes in the population. In Chile these changes have happened quickly in recent decades, resulting in an increase in the consumption of foods rich in cholesterol, saturated fats, sugar and sodium, among others, with the ensuing consequences of a high prevalence of obesity and non-communicable chronic diseases (ARANEDA et al., 2010). By contrast, in the last 10 years the consumption of $\mathrm{F} \& \mathrm{~V}$ has dropped, due to the perception that they are difficult to prepare, that they do not satisfy hunger, and also due to the fact that people prefers junk food (high in fat, sugar and salt), that their daily consumption are not part of the eating habits of the population, and that they are expensive (OLAVARRIA; ZACARIAS, 2011). These situations also affect young people. Various authors have described the nutritional vulnerability of university students whose eating habits are characterized by consuming insufficient amounts of $\mathrm{F} \& \mathrm{~V}$, among other problems (MARDONES et al., 2009 COSTA SILVA et al., 2012). This has negative repercussions on their physical health (COSTA SILVA et al., 2012), on their subjective well-being in general and on the domain of food (SCHNETTLER et al., 2013).

Subjective well-being is an assessment people make of their own lives. This evaluation includes 
cognitive and emotional aspects of experience. The cognitive component of subjective well-being is satisfaction with life, whether overall or by specific domains (DIENER et al., 1999). Numerous studies have addressed overall satisfaction with life and in certain domains, including food. Satisfaction with food-related life is defined as a person's overall assessment regarding their food and eating habits (GRUNERT et al., 2007). In this regard, recent studies have concluded that food counts among the important life domains that affect an individual's subjective well-being (GRUNERT et al., 2007; SCHNETTLER et al., 2013). It has been reported that there is a relation between satisfaction with food-related life and preferences for foods with different attributes (SCHNETTLER et al., 2010; SCHNETTLER et al., 2014). Therefore, it is expected that the preference for fruits with different attributes will differ according to one's satisfaction with foodrelated life.

Based on this background, the aim of this study was to identify and characterize consumer segments according to the importance and preference for the attributes type of fruit, package/brand, benefit associated with fruit consumption and price in a sample comprised of working adults and university students.

When making a purchase, consumers base their selection on different attributes before deciding and acquiring the product. However, products are conceived as a set of attributes, each one of which gives an indication that contributes to the formation of consumer preferences (GRUNERT et al., 1996). Foods have several attributes that can be classified by extrinsic and intrinsic quality. The former type is characterized by attributes that are easily understood by the consumer and that can be seen in the product externally. In the case of intrinsic quality, these attributes need to be stamped, certified or labeled so consumers can perceive them easily. Therefore, consumers use extrinsic indicators (e.g. brand name) to evaluate the intrinsic quality (RICHARDSON et al., 1994; PEREIRA, 2001; CUNHA et al., 2011). Based on the above, this study evaluates the importance and preference towards two extrinsic quality attributes, package/brand and price, and one intrinsic quality attribute related to nutritional value (benefit associated with fruit consumption), that must be presented to the consumer via an extrinsic signal such as labeling, in three different fruits.

\section{MATERIALS AND METHODS}

A personal survey was administered in Temuco, Region of the Araucanía, Chile, to a sample of 400 people. This number was obtained using the stratified random sampling formula with simple allocation for non-finite populations ( $>100,000)$, considering 95\% confidence and 5\% estimation error with $\mathrm{p}$ and $\mathrm{q}$ of 0.5 (FERNÁNDEZ, 2002). This sampling method was used due to the distinct characteristics of the two population segments under study (FERNÁNDEZ, 2002), while still allowing for representativity and control of the sample composition. Stratification is used to assure that the key groups have sufficient sample size for separate analysis (FRANKEL, 2013), and taking a random sample in a target population selected purposefully adds trustworthiness (rather than generalizability) to the findings (TASHAKKORI; TEDDLIE, 2003). Thus, 200 university students and 200 working adults were surveyed. The students were contacted on campuses of two universities in Temuco. Working adults were approached at the exit of two supermarkets in the same city. The surveys were applied by two previously trained interviewers between June and August 2013 after the questionnaire had been validated by means of a preliminary test with $10 \%$ of the sample. As the validation of the instrument was satisfactory, no changes were required in either the questionnaire or the interview procedure. The participants signed informed consent statements before responding. The questionnaire used contained closed questions to determine the weekly frequency of fruit consumption, the causes that explain daily consumption, the causes of less frequent consumption, and if the respondent associated fruit consumption with disease prevention. The questionnaire included the SWFL (Satisfaction with Food-related Life) scale. The SWFL was proposed and tested by Grunert et al. (2007) in eight European countries (Cronbach's $\alpha$ : 0.81-0.85). The five items on the scale are: Food and meals are positive elements; I am generally pleased with my food; my life in relation to food and meals is close to ideal; with regard to food, the conditions of my life are excellent; food and meals give me satisfaction in daily life. The respondents were asked to indicate their degree of agreement with these statements using a 6-level Likert scale (1: disagree completely, 6: agree completely). In this study, the SWFL showed a good level of internal consistency (Cronbach's $\alpha$ : 0.88). The classification questions included were: gender, age, area of residence, self-reported lifestyle, level of education of the head of the household, and the 
possession of ten domestic goods. These two last variables help determine the socioeconomic group, which was classified as $\mathrm{ABC} 1$ (high and middlehigh), C2 (middle-middle), C3 (lower-middle), D (low) and E (very low) (ADIMARK, 2004).

A conjoint analysis (CA) was employed to determine the acceptance of three fruits: apples, blueberries and strawberries. CA is a decompositional methodology that allows the relative importance of the attributes of a product and the part worth utility values for each level of an attribute to be estimated. The estimated part worth utility indicates how influential each level of an attribute is in the formation of consumer preferences for a particular combination, i.e., the degree of preference for each level of an attribute (HAIR et al., 1999). Table 1 shows the attributes and levels defined in the study. The levels established for the attribute "fruits" corresponded to three types of fruit, the production of which is important to the Region of the Araucanía. While the surface planted with apple trees in the region is the most important in the field of regional fruit farming, blueberry is in third place after the European hazelnut (ODEPA, 2015). The case for strawberry is different because the plantation field in La Araucanía is insignificant, but the development of its cultivation has been promoted in recent years as a productive alternative for small farmers in the region (CORFO, 2015). For the attribute "package/ brand" we used packaging bearing the brand of one of the principal fruit-exporting companies in Chile (Hortifrut), a foreign brand (Dole), a store brand of one of the major supermarket chains in Chile (Jumbo) and loose (unpackaged and unbranded), since these are the two forms of presentation in which the fruits studied are sold in the city. This attribute was included because previous studies in Chile have indicated that consumers respond positively to packaged and branded fruits (SCHNETTLER et al., 2011). For the attribute "benefit", the levels established were of no benefit, contains antioxidants and prevents diseases. The price levels were established based on current prices in the Temuco market for 1 kilogram of these fruits at the time of the survey (high: 3.15 US\$ $/ \mathrm{kg}$, medium: $2.42 \mathrm{US} \$ / \mathrm{kg}$, and low: $1.70 \mathrm{US} \$ /$ $\mathrm{kg})$. From these attributes and levels, a total of 108 combinations ( $3 \times 4 \times 3 \times 3)$ were obtained; however, to facilitate the respondents' answers, it was decided that a fractional factorial design would be used, obtained with the macro MktEx from the SAS Institute (KUHFELD, 2010). This allowed the number of stimuli to be reduced to fourteen with one specification for each attribute, taking the precaution of not including brand-name unpackaged fruit. The stimuli were presented to respondents in cards that combined verbal and graphic information. The verbal description used words to present the attributes and levels derived from the factorial designs. The graphical representation used as stimuli drawings, sketches or photographs (HAIR et al., 1999). The benefit for health and the price per kilogram was indicated verbally (in written form). Graphically, each fruit was presented in bulk and packaged/ branded, using photographs. Each respondent ordered the cards with the combination of attributes from the most to the least preferred, on a scale of 1 to 14 (1: the most preferred; 14: the least preferred). Two of these cards were used as holdout cases. Conjoint analysis was carried out using the transreg procedure of SAS 9.3. All four attributes were considered to be discrete variables. The relative importance that consumers gave to the different attributes and the utility values obtained for each level of the selected factors were determined. The Root Mean Square Error (RMSE) was calculated to measure the difference between the observed and the predicted data (KUHFELD, 2010). A hierarchical cluster analysis was chosen to determine consumer segments according to the partial utility scores of the levels of the attributes. Ward's procedure, which calculates the squared Euclidean distance, was carried out with the cluster procedure of SAS. The number of groups was obtained by observing the dendrogram and confirmed by the percentage change in the recomposed conglomeration coefficients. To describe the segments, a Pearson Chi-square test was applied for the discrete variables and a one-factor analysis of variance was applied for the continuous variables (99\% and 95\% confidence level). Because Levene's test indicated non-homogenous variances, the averages of variables with significant differences $(\mathrm{P} \leq 0.001$ or $\mathrm{P} \leq 0.05)$ were separated according to Dunnett's T3 test for multiple comparisons.

\section{RESULTS AND DISCUSSION}

In the total sample there were more women $(55.0 \%)$, urban residents $(92.5 \%)$, with a conservative lifestyle (53.8\%) and people from socioeconomic group $\mathrm{ABC} 1(25.8 \%)$ and $\mathrm{C} 2(34.6 \%)$. The greatest proportion of respondents consumed fruit "daily" $(50.5 \%)$, mainly for health reasons $(68.5 \%)$. The main causes of a lower consumption were: no habit of consuming fruit $(38.6 \%)$, do not like them $(17.8 \%)$ and preference for other desserts (16.8\%). $79.8 \%$ associated fruit consumption with disease prevention. The greatest proportion of the sample was satisfied (46.0\%) and extremely satisfied (31.2\%) 
with their food-related life according to the SWFL. The average age of the sub-sample of students was 21.5 years $(\mathrm{SD}=1.2)$ and of the working adults 45.6 years $(\mathrm{SD}=10.4)$.

Using a conjoint analysis, it was established that in the total sample the attributes of greatest importance in the purchase of fruits was brand, followed by the type of fruit and price and finally information about the health benefits. The signs of the utility values of the attribute levels indicated a preference for blueberry and strawberry and a rejection of apples. The respondents preferred packaged fruit with a brand over loose fruit, with greatest preference for the brand Dole. Likewise, preference was observed for the product with information about the benefit associated with fruit consumption over the product with no information at the low price (Table 2). The RMSE of the conjoint analysis was 0.19 , which indicated a good goodness of adjustment (KUHFELD, 2010). The greater importance assigned to brand contradicts previous studies on $\mathrm{F} \& \mathrm{~V}$, where brand was second to selection (BEHE, 2006; SCHNETTLER et al., 2011). In this respect, although quality is an important driver of consumers' choices when it comes to fruit product selection (PEROSA et al., 2012; HAYNESMASLOW et al., 2013); when the quality of a product is difficult to determine in the store, as is the case with foods, consumers rely more heavily on extrinsic quality cues such as brand, packaging and price (BREDAHL, 2004), which is consistent with the results of this study. The importance of the type of fruit agrees with a previous study in Chile (SCHNETTLER et al., 2011). However, in that study consumers preferred strawberries and rejected blueberries. This seems to indicate a change in consumer preferences, showing greater acceptance for a fruit that was introduced into Chile for export purposes, and was only introduced onto the domestic market a few years ago due to a drop in international prices and the exchange rate (SCHNETTLER et al., 2011). The importance assigned to price and preference for the lowest price confirms the results of studies reporting that the cost of F\&V affects their acceptance (BEHE, 2006; PEROSA et al., 2012; HAYNES-MASLOW et al., 2013). The lower importance assigned to health benefits can be attributed to most of the respondents associating fruit consumption with disease prevention $(79.8 \%$ of the total sample). Nevertheless, the results are consistent with those obtained by Geeroms et al. (2008) in terms of a positive response from the consumers to verbal arguments related to functional benefits of $\mathrm{F} \& \mathrm{~V}$ consumption. Additionally, the greater preference for "prevents diseases" information confirms the greater acceptance by consumer of consequence-related knowledge about functional food than knowledge only related to the functional ingredient (WASKING el al., 2005), as "contains antioxidants". Thus, it is possible to suggest that, in general, providing easyto-understand information on the benefits of fruit consumption may promote fruit consumption among consumers in Temuco.

A cluster analysis significantly distinguished $(\mathrm{P} \leq 0.001)$ three consumer segments in terms of the preferences for most of the levels of the attributes $(\mathrm{P} \leq 0.001)$, except in the case of apple and store brand $(\mathrm{P}>0.1)$. The groups also differed in the importance of the evaluated attributes $(\mathrm{P} \leq 0.05)$ (Table 2$)$. The groups differed significantly by self-declared lifestyle, activity, their level of satisfaction with food-related life $(\mathrm{P} \leq 0.05)$ (Table 3$)$ and age.

Group 1 "Brand conscious" $(\mathrm{n}=88,22.0 \%$ of the sample): gave greatest importance to brand $(33.3 \%)$, although did not differ statistically from Group 2. It showed the greatest preference for the Dole brand and the greatest rejection of loose fruit with no brand. The second attribute in importance was price, with greatest preference for the highest price. This group only preferred strawberries. Group 1 preferred the product with no information and with the message "prevents diseases" (Table 2). Group 1 presented the highest proportion of working adults $(69.5 \%)$ (Table 3$)$. The average age (56.5 years) was significantly higher than in Groups 2 and $3(\mathrm{P} \leq 0.05)$.

Group 2 "Benefit conscious" ( $\mathrm{n}=190$, 47.5\%): assigned greatest importance to brand, but was the one that gave the most importance to the information on health benefits $(20.7 \%)$. It showed the greatest preference for the message "prevents diseases" and the greatest rejection of fruit with no information. This group showed preference for both manufacturer brands (Table 2) and for both types of berry. These consumers preferred the lowest price. Group 2 presented the highest proportion of working adults $(59.8 \%)$ (Table 3$)$. The average age (43.1 years) was significantly higher than Group 3 $(\mathrm{P} \leq 0.05)$.

Group 3 "Price conscious" $(\mathrm{n}=122,30.5 \%)$ : gave greatest importance to price $(30.9 \%)$ and preferred the lowest price. Group 3 assigned greater relevance to the type of fruit. They preferred the blueberry over the other two alternatives. This group preferred the Hortifrut brand and among the benefits the message "contains antioxidants" (Table 2). Group 3 had the highest proportion of people with an innovative lifestyle (21.3\%), university students $(79.6 \%)$ and those who were dissatisfied $(9.8 \%)$ and 
somewhat satisfied $(9.8 \%)$ with their food-related life (Table 3). The average age of this group was 25.5 years.

These results indicate differences in the importance assigned to attributes and preferences under study by the consumers' age and occupation. Therefore, to increase the consumption of fruits different strategies should be adopted. Working adults value packaged fruit with a brand name, thus a commercial mix of these aspects in the fruit supply may increase fruit consumption. Likewise, a simple message like "prevents diseases" could improve acceptance in this type of consumer (Groups 1 and 2). This is consistent with the low level of knowledge regarding antioxidants in a previous study with adults in Chile (SCHNETTLER et al., 2011). Although the most of the sample preferred the lowest price (Groups 2 and 3), to improve acceptance in young people it is especially important that the fruit be priced accessibly. In these consumers a message related to the functional component of the fruit might increase its acceptance (contains antioxidants). This may indicate that young people have more knowledge than working adults on functional ingredients and their effect on health. The type of fruit plays an important role in consumer preferences; therefore, if the desire is to increase fruit consumption among young people, like university students, university cafeterias should offer the fruits they like.

Although no differences were detected in the frequency of fruit consumption between the groups and the relationship between higher fruit consumption and a greater subjective well-being could not be confirmed (BLANCHFLOWER et al., 2013), it is possible to indicate that young people have a lower level of subjective well-being in the domain of food. However, the differences in the degree of satisfaction with food-related life between the groups confirm the relation between satisfaction with food-related life and preferences for foods with different attributes (SCHNETTLER et al., 2010; SCHNETTLER et al., 2014). In line with the results of a recent study on acceptance of a vegetable with designation of origin in Temuco (SCHNETTLER et al., 2015), there may be a relation between the level of satisfaction with food-related life and the importance assigned to price. Group 3 assigned greatest importance to this attribute and showed greater sensitivity to the increase in price, at the same time concentrating the highest proportion of people dissatisfied and somewhat satisfied with their foodrelated life. In this regard, it is possible to suggest that if the consumer selects what foods to buy based mainly on price, clearly preferring the lowest, their satisfaction with food-related life can be reduced in light of the restriction that price imposes on access to the desired foods (SCHNETTLER et al., 2015).

TABLE 1- Design of the conjoint experiment.

\begin{tabular}{ccccc}
\hline Card & Fruit & Packaged/brand & Benefit for health & Price (US\$/kg) \\
\hline A & Apple & Without & Without & 2.42 \\
B & Strawberry & Without & Without & 2.42 \\
C & Blueberry & Without & Without & 3.15 \\
D & Apple & Dole & Without & 1.70 \\
E & Strawberry & Hortifrut & Contains antioxidants & 2.42 \\
F & Blueberry & Hortifrut & Prevents diseases & 3.15 \\
G & Apple & Dole & Contains antioxidants & 2.42 \\
H & Blueberry & Hortifrut & Contains antioxidants & 3.15 \\
I & Apple & Dole & Prevents diseases & 1.70 \\
J & Blueberry & Jumbo & Without & 3.15 \\
K & Strawberry & Jumbo & Contains antioxidants & 1.70 \\
L & Blueberry & Jumbo & Prevents diseases & 2.42 \\
M & Apple & Jumbo & Contains antioxidants & 3.15 \\
N & Strawberry & Hortifrut & Contains antioxidants & 2.42 \\
\hline
\end{tabular}

The national currency values (Chilean pesos) were converted to dollars using the average 2013 value (\$495.00 US\$). 
TABLE 2- Distribution and relative importance of the three clusters and overall sample based on preferences for fruits.

\begin{tabular}{lcccccc}
\hline Attribute \& Levels & $\begin{array}{c}\text { Total sample } \\
(\mathrm{n}=400)\end{array}$ & $\begin{array}{c}\text { Group 1 } \\
(\mathrm{n}=88)\end{array}$ & $\begin{array}{c}\text { Group 2 } \\
(\mathrm{n}=190)\end{array}$ & $\begin{array}{c}\text { Group 3 } \\
(\mathrm{n}=122)\end{array}$ & $\mathrm{F}$ & P-value \\
\hline Fruit & & & & & & \\
$\quad$ Blueberry & 1.09 & $-1.52 \mathrm{c}$ & $0.56 \mathrm{~b}$ & $3.82 \mathrm{a}$ & 131.752 & 0.000 \\
$\quad$ Strawberry & -1.15 & -1.36 & -1.09 & -1.16 & 0.437 & 0.646 \\
$\quad$ Apple & 25.8 & $24.1 \mathrm{~b}$ & $25.5 \mathrm{ab}$ & $27.5 \mathrm{a}$ & 3.476 & 0.032 \\
$\quad$ Relative importance (\%) & & & & & & \\
Brand & 1.03 & $4.08 \mathrm{a}$ & $0.92 \mathrm{~b}$ & $-0.99 \mathrm{c}$ & 91.669 & 0.000 \\
$\quad$ Dole & 0.23 & $-0.77 \mathrm{~b}$ & $0.02 \mathrm{~b}$ & $1.28 \mathrm{a}$ & 14.679 & 0.000 \\
$\quad$ Hortifrut & 0.01 & 0.32 & -0.06 & -0.12 & 1.470 & 0.231 \\
$\quad$ Jumbo & -1.27 & $-3.63 \mathrm{~b}$ & $-0.88 \mathrm{~b}$ & $-0.17 \mathrm{a}$ & 49.073 & 0.000 \\
$\quad$ Without brand/packaged & 29.8 & $33.3 \mathrm{a}$ & $32.2 \mathrm{a}$ & $23.6 \mathrm{~b}$ & 39.678 & 0.000 \\
$\quad$ Relative importance (\%) & & & & & & \\
Benefit & 0.05 & $-1.68 \mathrm{c}$ & $-0.16 \mathrm{~b}$ & $1.62 \mathrm{a}$ & 78.305 & 0.000 \\
$\quad$ Contains antioxidants & 0.18 & $0.79 \mathrm{a}$ & $0.87 \mathrm{a}$ & $-1.33 \mathrm{~b}$ & 60.215 & 0.000 \\
$\quad$ Prevents diseases & -0.23 & $0.89 \mathrm{a}$ & $-0.71 \mathrm{~b}$ & $-0.29 \mathrm{~b}$ & 19.653 & 0.000 \\
$\quad$ Without & 19.0 & $16.5 \mathrm{~b}$ & $20.7 \mathrm{a}$ & $18.0 \mathrm{~b}$ & 8.038 & 0.000 \\
$\quad$ Relative importance $(\%)$ & & & & & & \\
Price & 0.48 & $-3.59 \mathrm{c}$ & $0.45 \mathrm{~b}$ & $3.46 \mathrm{a}$ & 310.163 & 0.000 \\
$\quad$ Low U\$1.70/kg & -0.09 & $0.44 \mathrm{a}$ & $-0.73 \mathrm{~b}$ & $0.51 \mathrm{a}$ & 21.069 & 0.000 \\
$\quad$ Medium US $2.42 / \mathrm{kg}$ & -0.39 & $3.15 \mathrm{a}$ & $0.28 \mathrm{~b}$ & $-3.97 \mathrm{c}$ & 342.690 & 0.000 \\
$\quad$ High $\$ 3.15 / \mathrm{kg}$ & 25.4 & $26.1 \mathrm{~b}$ & $21.6 \mathrm{c}$ & $30.9 \mathrm{a}$ & 34.620 & 0.000 \\
$\quad$ Relative importance $(\%)$ &
\end{tabular}

Utility numbers in the different levels for an attribute with minus sign indicate utility loss for the consumer. Bigger negative numbers indicate higher utility loss. Different letters in the line indicate significant differences according to Dunnett's T3 multiple comparison test $(\mathrm{P} \leq 0.05)$. "a" is significantly higher than " $\mathrm{b}$ ". " $\mathrm{b}$ " is significantly higher than "c".

TABLE 3- Characteristics with significant differences in the groups identified by cluster analysis.

\begin{tabular}{|c|c|c|c|}
\hline Characteristic & $\begin{array}{c}\text { Group } 1 \\
(\mathrm{n}=88)\end{array}$ & $\begin{array}{l}\text { Group } 2 \\
(\mathrm{n}=190)\end{array}$ & $\begin{array}{c}\text { Group } 3 \\
(\mathrm{n}=122)\end{array}$ \\
\hline Lifestyle & & $\mathbf{P}=\mathbf{0 . 0 1 0}$ & \\
\hline Conservative & 60.2 & 57.4 & 43.4 \\
\hline Liberal & 15.9 & 21.6 & 17.2 \\
\hline Sportsperson & 8.0 & 12.1 & 15.6 \\
\hline Innovative & 12.5 & 8.4 & 21.3 \\
\hline Other & 3.4 & 0.5 & 2.5 \\
\hline Activity & & $P=0.015$ & \\
\hline University students & 30.5 & 40.2 & 79.6 \\
\hline Working adults & 69.5 & 59.8 & 20.4 \\
\hline Satisfaction with food-related life & & $P=0.015$ & \\
\hline Dissatisfied & 2.3 & 2.4 & 9.8 \\
\hline Somewhat satisfied & 10.3 & 13.2 & 17.6 \\
\hline Satisfied & 55.1 & 52.3 & 41.8 \\
\hline Extremely satisfied & 31.3 & 32.1 & 30.8 \\
\hline
\end{tabular}

P values obtained by Chi-squared test. 


\section{CONCLUSIONS}

Using conjoint and cluster analyses, three consumer segments were distinguished in Temuco, Chile: Group 1 (22.0\%) gave greatest importance to the package/brand of fruit and preferred the message "prevents diseases" and "without information"; Group $2(47.5 \%)$ gave greatest importance to the package/brand and preferred the message "prevents diseases"; Group $3(30.5 \%)$ assigned greatest importance to the price and preferred the message "contains antioxidants". The segments differed in the preference for the three types of fruits evaluated their level of satisfaction with food-related life, selfdeclared lifestyle, age and presence of university students.

The three segments valued the fruit packaged with a brand, which could increase its acceptance. The older segments may respond positively to a simple message on the package about the health benefits of consuming fruit (prevents diseases). The younger segment comprised mainly of university students may respond positively to a message indicating the functional component of the fruit (contains antioxidants) and to an accessible price.

Therefore, from a commercial point of view, fostering increased consumption of fruits on university students and working adults should be approached with a differentiated marketing strategy. The commercial mix mainly intended for working adults should consider offering fruit packaged with a brand, as it is possible to expect that some of these consumers are willing to pay a higher price associated with these attributes (Group 1). By contrast, the commercial mix focused on university students should consider a lower price to increase demand, which should be implemented in university cafeterias. To increase fruit consumption in both groups it may be positive to include information related to the health benefits associated with fruit consumption. While the results of the study indicate that university students have greater knowledge about the benefits associated with the functional component of the fruit, and that working adults react more positively to understandable information, it would be advisable for marketing strategies to be accompanied by information campaigns led by the Ministry of Health. These should focus on increasing awareness of consumers about the various functional components of fruits and their health benefits.

Future research should investigate the acceptance of other functional components of fruits, and other associated health effects in different population segments, in order to provide input to improve people's objective and subjective quality of life.

\section{ACKNOWLEDGMENTS}

The results presented correspond to Fondecyt Project 1130165.

\section{REFERENCES}

ADIMARK. Mapa socioeconómico de Chile. Santiago, Chile: Adimark, Investigación de Mercados y Opinión Pública, 2004. Disponível em: http:// www.adimark.cl. Acesso em: 12 abr. 2005.

ARANEDA, J.; AMIGO, H.; BUStos, P. Características alimentarias de adolescentes chilenas indígenas y no indígenas. Archivos Latinoamericanos de Nutrición, Caracas, v. 60, n. 1, p. 30-35, 2010.

BEHE, B. Conjoint analysis reveals consumers prefer long, thin asparagus spears. Hortscience, St Joseph, v. 41, n. 5, p. 1259-1262, 2006.

BLANCHFLOWER, D.; OSWALD, A.; STEWARTBROWN, S. Is psychological well-being linked to the consumption of fruit and vegetables? Social Indicators Research, Dordrecht, v. 114, p. 785801, 2013.

BREDAHL, L. Cue utilization and quality perception with regard to branded beef. Food Quality and Preference, Harlow, v. 15, n. 1, p. 65-75, 2004.

CIREN - Centro de Información de Recursos Naturales. Catastro frutícola. Principales resultados Región de La Araucanía, Julio 2012. Disponível em: $<\mathrm{http}$ ///bibliotecadigital.ciren.cl/gsdlexterna/collect/ bdirenci/index/assoc/HASHee33.dir/cfpr09_2012. pdf $>$. Acesso em: 14 abr. 2015.

CORFO - Corporación Nacional de Fomento. Repositorio digital 2015. Disponível em: $\leq$ http:// repositoriodigital.corfo.cl/handle/11373/1492/disc over?fq=title $\% 3 \mathrm{~A} \% 28$ araucan $\% \mathrm{C} 3 \% \mathrm{ADa} \% 29 \& \mathrm{fi}$ tertype=title\&filter $=$ frutilla\&submit search-filtercontrols add $=$ Ir\&query $=$ frutilla + araucan $\% \mathrm{C} 3 \% \mathrm{~A}$ Da\&rpp $=10>$. Acesso em: 14 abr. 2015. 
COSTA SILVA, J.; BARRETOI, L.; CASTRO, L. DE.; DUARTE, G.; TOYOMI, A.; SACHS, A. Lipid profile and cardiovascular risk factors among first-year Brazilian university students in São Paulo. Nutrición Hospitalaria, Madrid, v. 6, n. 3, p. 553559, 2011.

CUNHA, C. F; SPERS, E. E; ZYLBERSZTAJN, D. Percepção sobre atributos de sustentabilidade em um varejo supermercadista, Revista de Administração de Empresas, São Paulo, v. 51, n. 6, p. 542-552, 2011.

DIENER, E.; SUH, E.; LUCAS, R.; SMITH, H. Subjective well-being: three decades of progress. Psychological Bulletin, Washington, v. 125, n. 2, p. 276-302, 1999.

FERNÁNDEZ, A. Investigación y Técnicas de Mercado. Madrid: Editorial Esic, 2002. p.273.

FRANKEL, M. Sampling theory. In: P. ROSSI, P.; WRIGHT, J.; ANDERSON, A. Handbook of survey research. Quantitative studies in social relations. Massachusetts: Academic Press, 2013. p.774.

GEROOMS, N.; VERBEKE, W.; VAN KENHOVE, P. Health advertising to promote fruit and vegetable intake: Application of health-related motive segmentation. Food Quality and Preference, Harlow, v. 19, p. 481-497, 2008.

GRUNERT, K. G.; BAADSGAARD, A.; LARSEN, H. H.; MADSEN, T. K. Market orientation in food and agriculture. Massachussetts: Kluwer Academic Publishers, 1996.

GRUNERT, K. G.; DEAN, D.; RAATS, M.; NIELSEN, N.; LUMBERS, M. A measure of satisfaction with food-related life. Appetite, London, v. 49, n. 2, p. 486-493, 2007.

HAIR, J.; ANDERSON, R.; TATHAM, R.; BLACK, W. Análisis multivariante. Madrid: Prentice Hall Internacional, 1999. p.832.

HAYNES-MASLOW, L.; PARSONS, S. E.; WHEELER, S. B.; LEONE, L. A. A Qualitative study of perceived barriers to fruit and vegetable consumption among Low-Income populations. North Carolina, 2011. Preventing Chronic Disease, Atlanta, v.10, n.120-206, 2013.
KUHFELD, W. Marketing research methods in SAS. Experimental design, choice, conjoint and Graphical techniques. SAS 9.2 2010. Disponível em: $\leq$ http://support.sas.com/techsup/technote/mr2010. pdf >. Acesso em: 15 nov. 2012.

MARDONES, MA.; OLIVARES, S; ARANEDA, J.; GÓMEZ, N. Etapas del cambio relacionadas con el académico de frutas y verduras, actividad física y control del peso en estudiantes universitarios chilenos. Archivos Latinoamericanos de Nutrición, Caracas, v. 59, n. 3, p. 304-309, 2009.

ODEPA - Oficina de Estudios y Políticas Públicas. Panorama de la agricultura chilena. 2013. Disponível em: $\leq$ http://www.odepa.cl/wp-content/ files mf/1391691872Panoramadelaagriculturachile na2013.pdf $>$. Acesso em: 14 abr. 2015.

ODEPA - Oficina de Estudios y Políticas Públicas. Superficie de frutales por región. 2015. Disponível em: $<$ http://www.odepa.cl/superficie-de-frutales-porregion-2/>. Acesso em: 14 abr. 2015.

OLAVARRIA, S.; ZACARIAS, I. Obstaculizadores y facilitadores para aumentar el consumo de frutas y verduras en seis países de Latinoamérica. Archivos Latinoamericanos de Nutrición, Caracas, v. 61, n. 2, p. 154-162, 2011.

PEROSA, J.M.Y.; TARSITANO, M.A.A.; MARTINS, M.I.E.G.; PIGATTO, G.; ANTONANGELO, A. Perfil do consumidor de frutas em cidades do interior do estado de São Paulo - SP. Revista Brasileira de Fruticultura, Jaboticabal, v.34, n.4,p.1084-1090, 2012.

PELAYO, C. Las frutas y hortalizas como alimentos funcionales. ContactoS, Iztapalapa, v. 47, p. 12-19, 2003.

PEREIRA, I. Marcas de supermercado. Revista de Administração de Empresas, São Paulo,v.41, n. 1, p. 16-27, 2001.

RICHARDSON, P.; DICK, A.; JAIN, A. K. Extrinsic and intrinsic cue effects on perception of store brand quality. Journal of Marketing, New York, v. 58, n. 4, p. 28-36, 1994. 
SCHNETTLER, B.; SHENE, C.; RUBILAR, M.; MIRANDA, H.; SEPÚLVEDA, J.; DENEGRI, M.; LOBOS, G. Aceptación hacia yogurt con diferentes ingredientes funcionales en consumidores de supermercados del sur de Chile. Archivos Latinoamericanos de Nutrición, Caracas, v. 60, n. 4, p. 380-390, 2010.

SCHNETTLER, B.; MIRANDA, H.; SEPÚLVEDA, J.; DENEGRI, M.; MORA, M.; LOBOS, G. Preferences for berries among consumers in southern Chile: blueberries are produced but are they consumed? Journal of Food Science, Oxford, v. 76, n. 7, p. S458-464, 2011.

SCHNETTLER, B.; DENEGRI, M.; MIRANDA, H.; SEPÚLVEDA, J.; ORELLANA, L.; PAIVA, G.; GRUNERT, K. G. Hábitos alimentarios y bienestar subjetivo en estudiantes universitarios del sur de Chile. Nutrición Hospitalaria, Madrid, v. 28, n. 6, p. 2221-2228, 2013.

SCHNETTLER, B.; CRISÓSTOMO, G.; MORA, M.; LOBOS, G.; MIRANDA, H.; GRUNERT, K.G. Acceptance of nanotechnology applications and satisfaction with food-related life in southern Chile. Food Science and Technology, Campinas, v. 34, n. 1, p. 157-163, 2014.

SCHNETTLER, B.; PIHÁN, R.; VALDEVENITO, A.; MIRANDA, H.; LOBOS, G.; GRUNERT, K. G. Acceptance of a vegetable with designation of origin in two cities in southern Chile. Revista de la Facultad de Ciencias Agrarias, Mendoza, v. 47, n.1, 2015 .
TASHAKKORI, A.; TEDDLIE, C. Handbook of mixed methods in social $\&$ behavioral research. United Kingdom: Sage, 2003. p.768.

VAN DUYN, M. A.; PIVONKA, E. Overview of the health benefits of fruit and vegetable consumption for the dietetics professional: Selected literature. Journal of the American Dietetic Association, Chicago, v.100, n.12, p.1511-1522, 2000.

VERBEKE, W.; PIENIAK, Z. Benefit beliefs, attitudes and behaviour towards fresh vegetable consumption in Poland and Belgium. Acta Alimentaria, Budapest, v.35, p.5-16, 2006.

WANSINK, B.; WESTGREN, R. E.; CHENEY, M. $\mathrm{M}$. Hierarchy of nutritional knowledge that relates to the consumption of a functional food. Nutrition, New York, v.21, p.264-268, 2005.

WHO - World Health Organization. Fomento del consumo mundial de frutas y verduras. Geneva. 2003. Disponível em: $<\mathrm{http} / / / \mathrm{www}$.who.int/ dietphysicalactivity/fruit/es/index1.html>. Acesso em: 22 dez. 2012. 